\title{
The impact of brand image fit on attitude towards a brand alliance
}

\author{
Debra RILEY
}

Kingston University, Kingston-upon-Thames, UK

Nathalie CHARLTON

Kingston University, Kingston-upon-Thames, UK

Hillary WASON

Kingston University, Kingston-upon-Thames, UK

\begin{abstract}
Co-branding has become an increasingly popular strategy over recent decades. Studies have found that the pre-existing attitudes to the parent brands, fit between their product categories and perceived fit in the brands themselves as important drivers of a co-brand success. Despite its importance, most studies have treated brand fit as a simple measure of complementarity and consistency. Recently, a few papers have challenged this view, suggesting that a broader range of brand attributes (such as personality, functional and hedonic characteristics, cultural meaning) should also be considered when investigating brand alliances. The current study draws on these findings, exploring the fit between partners' brand images and how they influence perceptions of a brand alliance. We treat brand image as a multi-dimensional construct, consisting of economic, symbolic, sensory, futuristic and utilitarian elements. Using an experimental design with nine hypothetical brand pairings with 221 respondents, we find brand image fit provides greater explanatory power over a traditional unidimensional measure of brand fit, with economic, futuristic and utilitarian dimensions having a significant influence on co-brand perceptions.
\end{abstract}

Keywords: co-branding, brand alliance, brand image, brand fit, partial-least squares.

Please cite the article as follows: Riley, D., Charlton, N. and Wason, H. (2015), "The Impact of Brand Image Fit on Attitude towards a Brand Alliance", Management \& Marketing. Challenges for the Knowledge Society, Vol. 10, No. 4, pp. 270-283, DOI: 10.1515/mmcks-2015-0018.

\section{Introduction}

The popularity of co-branding as a brand management strategy has grown steadily over the past 20 years. Co-branding combines the competencies and reputations of two partnering brands to create a new product (e.g. Park et al., 1996; Faems et al., 2005). Past research has identified important determinants of consumer attitudes to cobrands, such as familiarity with the parent (i.e. partner) brands (Levin and Levin, 2000), the perceived quality of the partners (Rao and Ruekert, 1994; Rao et al., 1999), and their relative brand equity (Washburn et al., 2000). In particular, the extent to which partner brands are perceived to 'fit', (i.e. be congruent in terms of brand perceptions and product categories) has been found to influence consumer attitudes to the co-brand (Baumgarth, 2004; Helmig et al., 2007; Lafferty et al., 2004; Simonin and Ruth, 1998). One would expect the similarity between partner brand to increase the fit perception (Simonin and Ruth, 1998) but moderate incongruity has been seen to foster favourable evaluations as well (Meyers-Levy and Tybout, 1989).

Correspondence: Riley Debra d.riley@kingston .ac.uk 
A limitation of research to date is that partner brand characteristics have not been widely explored. Most studies have created co-brands based on familiarity (e.g. Simonin and Ruth, 1998; Baumgarth, 2004), equity levels (e.g. Washburn et al., 2000, 2004; Besharat, 2010) or vertical integration (Desai and Keller, 2002). Recent research suggests this dichotomous view of brand partnerships may be limiting. Singh et al. (2014) found consumer perceptions of the varying positioning strategies of partner brands to be a significant determinant of the positioning perceptions of the cobrand offering. Van der Lans et al. (2014) found that conceptual coherence in brand personality profiles (rather than brand equity) between parent brands predicts attitudes toward a brand alliance. In tandem, a few scholars are broadening the perspective of fit between partner brands. For instance, Bouten et al. (2011) considered the match between the new product and parent brand, and also examined the country of origin fit (Bluemelhuber et al., 2007; Lee et al. 2013). Although brand fit continues to be operational as a two- or three-item construct including complementarity and consistency (e.g. Lee et al., 2013), few papers have adopted a more nuanced view. A study by James et al. (2006) considered brand personality traits of partner brands in an alliance; their results suggest that a broader notion of brand fit is needed. Xiao and Lee (2014) introduce the concept of brand identity (BI) fit, finding different co-brand evaluations for low versus high BI fit scenarios.

We build on the above research to consider brand fit as a multi-dimensional rather than a unidimensional construct. We draw on brand image research (Keller, 1993; Romaniuk et al., 2012; Salinas and Perez, 2009; Hsieh and Lindridge, 2005) to develop and test the impact of attitudes toward the parent brands, fit characteristics and brand familiarity on attitudes towards a co-branded product. The paper is organized as follows. First we briefly review the literature on brand alliances (referred to interchangeably as co-branding), looking specifically at issues of brand fit. We then discuss the brand image literature and identify relevant dimensions. A conceptual framework is developed and tested with 221 students. We conclude with managerial and theoretical implications, and suggestions for further research.

\section{Theoretical background}

\section{Brand alliance and brand fit}

The theoretical foundations of co-branding's impact on consumers come from theories on signalling (Rao and Ruekert, 1994; Rao et al., 1999), and attitude formation (e.g. Anderson, 1981; Hillyer and Took, 1995). Signalling theory suggests firms need to find a way to communicate the products' information to the buyers. Previous alliance studies demonstrate that brands prove beneficial if they can signal high quality cues that transfer to the other partner brand or provide information on product attributes that benefits the alliance (Rao and Ruekert, 1994). Attitude formation frameworks include the elaboration likelihood model (Petty and Cacciopio, 1986) and context effects (Lynch et al., 1991), suggesting that pre-existing, salient and accessible brand attitudes and close, observable cues influence consumer perceptions of a brand partnership. The 'fit' between two brands has been found to be an important factor influencing perceptions.

Park et al. (1991) refer to fit as the process in which consumers determine the suitability of a new product under a given brand. In brand alliance research, the term fit is used to describe how the participating products or brands are perceived to be a suitable combination to each other, and is often used interchangeably with terms like 'congruence', 'similarity' or 'match up' (Simonin and Ruth, 1998; Zdravkovic et al., 2010). Irrespective of the terminology applied, research agrees that fit, especially 
MMCKS brand fit, is an important concept in brand alliances. If a consumer's associations with one partner match the associations of the other partner, it leads to an increase in recall

272 and an easier formation of new associations in his/her memory. It also affects the consumer's ability to learn new brand in formation (Walchi, 2007). In contrast, incongruent images lead to attributional search, raising questions about the alliance, and can lead to negative judgements (Folkes, 1988).

Aaker and Keller (1990) were among the first to emphasize the importance of the fit in a brand extension context. They found that the fit between the product class of the parent brand and the brand extension increases consumer's evaluation of the extension in terms of quality image. Aaker and Keller's model was applied to the context of brand alliances, focusing on complementary and/or cohesiveness of the partner brands image and product category to conceptualize fit, with empirical findings confirming its importance (e.g. Park et al., 1996; Simonin and Ruth, 1998; Baumgarth, 2004). A review of studies of brand fit in co-branding suggests there has been little subsequent development in its operationalization (see Table 1). Many studies have relied on pairings of high/low equity brands, which do not necessarily help managers determine what brand characteristics are desirable in a partner. Three studies have considered a broader notion of brand fit. James et al. (2006) explore brand personality dimensions of partner brands in an alliance. Their findings suggest that purchase likelihood of a co-brand is increased if the brand personalities of the parents are perceived to be a good fit. Lanseng and Olsen (2012) reveal different outcomes for partnerships between functional and expressive brands, but do not operationalize the fit measure. Similarly, Xiao and Lee (2014) consider the perceived congruence/incongruence between two brands' cultural meanings, investigating pairs of brands that are matched (or mismatched) on the basis of their brand identities, finding differing perceptions of the co-branded product.

The previous discussion suggests that a broader definition of brand fit would be useful when evaluating brand alliance outcomes. We turn now to studies of brand image and brand extensions in order to identify key dimensions for consideration.

\section{Brand image}

Brand image has been an important concept in consumer behaviour research since the 1950's. It has been associated with the metaphor of "brand as a person" or the image of the user (Biel, 1993). A brand can be characterized by unique personality traits and dimensions, which provide consumers with the means to express themselves (Belk, 1988; Malhotra, 1988). This view of brand image is consistent with the symbolic meaning of consumption where consumers exploit brands to construct and maintain their identity (Fiske, 1989) and experience emotional gratification (O' Donohoe, 1994).

In their review of brand image research, Dobni and Zinkhan (1990) found little consensus on how brand image should be defined or operationalized. They highlight a developing multi-component view of brand alliance measurement (Friedmann, 1986; Gensch, 1978; Reynolds and Gutman, 1984) that considers functional product qualities as well as psychological qualities of both the user and the product.

Table 1: Empirical studies of fit in brand alliances (chronological)

\begin{tabular}{|c|c|c|c|c|c|}
\hline Study & $\begin{array}{c}\text { Partner } \\
\text { brand pre- } \\
\text { attitudes }\end{array}$ & $\begin{array}{c}\text { Product } \\
\text { fit }\end{array}$ & $\begin{array}{c}\text { Brand fit } \\
\text { measures }\end{array}$ & $\begin{array}{c}\text { Familiarity } \\
\text { as moderating } \\
\text { variable }\end{array}$ & $\begin{array}{c}\text { Additional } \\
\text { measures/ } \\
\text { Comments }\end{array}$ \\
\hline
\end{tabular}




\begin{tabular}{|c|c|c|c|c|c|}
\hline $\begin{array}{l}\text { Simonin and } \\
\text { Ruth, } 1998\end{array}$ & Significant & Significant & $\begin{array}{l}\text { Consistency/ } \\
\text { Complementarity } \\
\text { Significant }\end{array}$ & Significant & \\
\hline $\begin{array}{l}\text { Baumgarth, } \\
2004\end{array}$ & Significant & Significant & $\begin{array}{l}\text { Consistency/ } \\
\text { Complementarity } \\
\text { Significant }\end{array}$ & $\begin{array}{l}\text { Not } \\
\text { significant }\end{array}$ & $\begin{array}{l}\text { Moderators brand } \\
\text { consciousness and } \\
\text { need for cognition } \\
\text { have small effects }\end{array}$ \\
\hline $\begin{array}{l}\text { Lafferty et al., } \\
2004\end{array}$ & Significant & $\begin{array}{l}\text { Not } \\
\text { significant }\end{array}$ & \begin{tabular}{|l|} 
Consistency/ \\
Complementarity \\
Makes sense \\
Significant \\
\end{tabular} & Significant & \\
\hline $\begin{array}{l}\text { Rodrigue and } \\
\text { Biswas, } 2004\end{array}$ & Significant & - & - & - & $\begin{array}{l}\text { Moderating effects of } \\
\text { dependency and } \\
\text { exclusivity }\end{array}$ \\
\hline $\begin{array}{l}\text { James et al., } \\
2006\end{array}$ & & - & \begin{tabular}{|l|} 
Brand personality \\
traits (14 items from \\
Batra et al., 1993) \\
Significant
\end{tabular} & 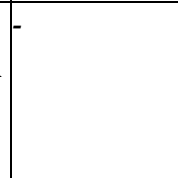 & \\
\hline $\begin{array}{l}\text { Bluemelhuber } \\
\text { et al., } 2007\end{array}$ & Significant & Significant & $\begin{array}{l}\text { Consistency/ } \\
\text { Complementarity } \\
\text { Significant }\end{array}$ & Significant & $\begin{array}{l}\text { Country of origin fit } \\
\text { also influences } \\
\text { attitude }\end{array}$ \\
\hline $\begin{array}{l}\text { Dickinson and } \\
\text { Barker, } 2007\end{array}$ & Significant & Significant & - & Significant & \\
\hline $\begin{array}{l}\text { Helmig et al., } \\
2007\end{array}$ & Significant & Significant & $\begin{array}{l}\text { Consistency/ } \\
\text { Complementarity / } \\
\text { Endorsing each } \\
\text { other } \\
\text { Significant }\end{array}$ & - & $\begin{array}{l}\text { Product fit and brand } \\
\text { fit should be } \\
\text { considered as two } \\
\text { dimensions of } \\
\text { complex construct } \\
\text { (overall fit) }\end{array}$ \\
\hline \begin{tabular}{|l|} 
Bouten, \\
Snelders, and \\
Hultink, 2011 \\
\end{tabular} & & Significant & Significant & - & $\begin{array}{l}\text { Effect of new } \\
\text { product- brand fit on } \\
\text { attitude }\end{array}$ \\
\hline $\begin{array}{l}\text { Lanseng and } \\
\text { Olsen 2012 }\end{array}$ & Significant & Significant & $\begin{array}{l}\text { Distinguishes } \\
\text { between functional } \\
\text { and expressive } \\
\text { brands on 6-item } \\
\text { scale } \\
\text { Significant }\end{array}$ & & \\
\hline Lee et al., 2013 & Significant & - & - & - & Country of origin fit \\
\hline $\begin{array}{l}\text { Xiao and Lee } \\
2014\end{array}$ & & - & \begin{tabular}{|l|} 
Brand identity: \\
perceived \\
congruence between \\
brands cultural \\
meanings \\
Significant
\end{tabular} & 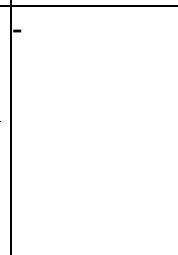 & $\begin{array}{l}\text { Co-brand attitude } \\
\text { also affected by } \\
\text { consumer } \\
\text { identification with } \\
\text { the focal brand } \\
\text { partner }\end{array}$ \\
\hline
\end{tabular}

Source: Authors' own research.

More recently authors have distinguished different types of brand associations based on attributes, benefits and attitudes that exist at varying levels of abstraction (Bhat and Reddy, 1998; Farquhar and Herr, 1991; Keller, 1993; Kirmani and Zeithaml, 1991). Whilst many studies have considered brand personality as the conceptual foundations of brand image (Aaker, 1996; Martizinez and Cheratony, 2004; Martinez and Pina, 2003), 
MMCKS others disagree (Low and Lamb, 2000; Azoulay and Kaferer, 2003; Austin et al., 2003). The large literature on brand equity has often considered brand image as a constituent 274 component, capturing it directly (e.g. Buil et al., 2008; Washburn and Plank, 2002; Pappu et al., 2005) or through intermediate measures such as utility (Vasquez et al., 2002; Kocak et al., 2007)

Park et al. (1986) considered three different types of benefits as dimensions of brand image that correspond to a range of consumer needs: functional benefits - which describe the consumers' need to solve consumption related problems; symbolic benefits - that fulfil the consumers' need for self-enhancement, ego identification, etc.; and experiential benefits - which meet consumers' desire for sensory or cognitive pleasure. Low and Lambe (2000) developed a category-specific measure of brand image comprised of six items. Adopting this approach, Hsieh and Lindridge (2006) developed a benefits-based multi-dimensional brand image construct that consists of sensory, utilitarian, symbolic, economic and futuristic image brand associations.

In the context of brand extensions, recent research by Martinez and de Chernatony (2004) and Martinez and Pina (2003) reveals that poorly perceived brand image fit will lead to the dilution of a parent brand. In the context of brand extension, dilution is deemed to occur when the beliefs or feelings regarding the parent brand are negatively impacted as a consequence of the brand (Loken and John, 1993; Ries and Trout, 1986; McCarthy et al., 2001), although empirical findings have been mixed (Kim and Roedder John, 2008; Diamantopolous et al., 2005).

\section{Conceptual framework}

The widely adopted framework by Simonin and Ruth (1998) considers parent brand attitudes, brand fit, and product fit to influence brand alliance attitudes, with familiarity with the parent brands moderating these relationships. Based on the discussion in the previous studies, we anticipate that including a multidimensional measure of brand fit will result in a model with a greater explanatory power.

As the study is exploratory in nature, we compare the original Simonin and Ruth (1998) framework (without feedback effects) against a model that incorporates a multidimensional view of brand image (Figure 1). In the first model, we consider brand fit as a two-item measure capturing consistency and complementarity (Simonin and Ruth, 1998). In the second, we operationalize brand image fit as a five dimensional measure, drawing on work by Hsieh and Lindridge (2005). 


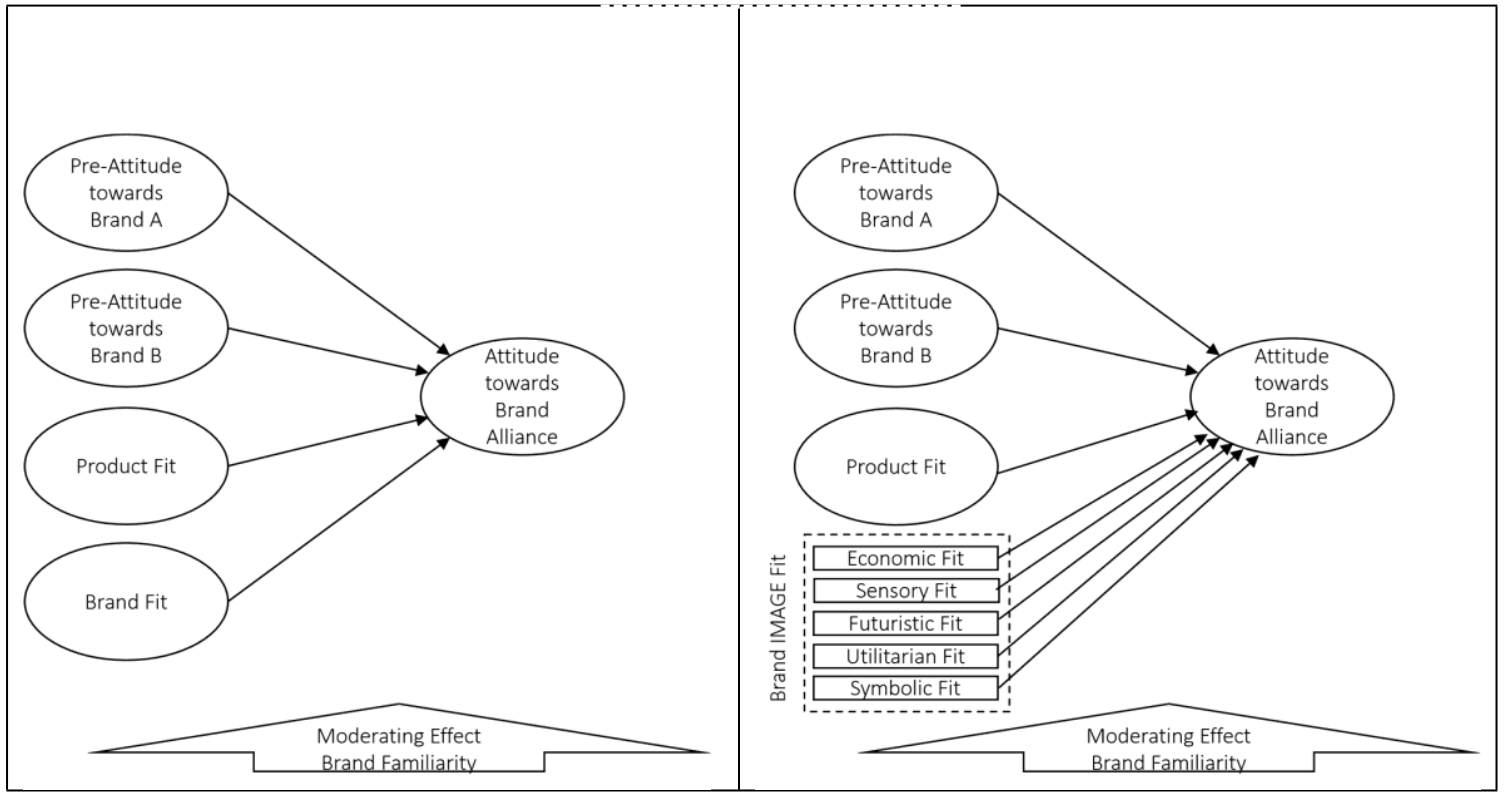

Figure 1. Frameworks for comparison

Source: Adapted from the model of Simonin and Ruth (1998).

\section{Method}

In line with most of the co-branding research to date, this study takes the form of a scenario based experimental design using nine hypothetical brand pairings. The cobrands selected were combinations of mobiles phones (A: Apple, Samsung, HTC) and watches (B: Rolex, Fossil, Swatch) considered to have a range of brand image associations and equity levels. Product and brand selections were pre-determined through a pilot focus group with ten consumers.

The main study respondents were undergraduate and postgraduates students from a UK university, and each respondent was randomly assigned to one of the brand alliances. In line with previous studies, the respondents were asked to indicate their perceptions of each brand (pre-alliance); questions related to brand and product fit followed before each of the brand alliances were presented in the form of pictorial representations (advertisement - see Appendix). Questions about attitudes towards each brand alliance and post-alliance questions about market position completed the survey. A total of 221 usable replies were obtained and compared between the nine cobrands.

Measures of pre-alliance attitudes, product fit and familiarity were adopted from Simonin and Ruth (1998), and operationalized as 7-point Likert-type scales. The measures used to capture brand image fit were adapted from Hsieh and Lindridge (2005) and consisted of five dimensions of perceived fit: economic, symbolic, sensory, futuristic and utilitarian, each measured by four items on a 7-point scale. Category relevant dimensions were identified through focus group discussion using existing print adverts and company websites. Table 2 presents the items developed. 
Table 2. Brand image dimensions

\begin{tabular}{|c|c|c|}
\hline & & \\
\hline MMCKS & Dimension & \begin{tabular}{|l|l|} 
Items \\
\end{tabular} \\
\hline 276 & Economic fit & \begin{tabular}{|l}
$\begin{array}{l}\text { Fit between the brands in terms of } \\
\text { perceived price/ value }\end{array}$ \\
Price level \\
Affordability \\
Price fairness
\end{tabular} \\
\hline & Symbolic fit & $\begin{array}{l}\text { Fit in terms of perceived symbolic benefits } \begin{array}{l}\text { Luxury features } \\
\text { that the consumer might have if he } \\
\text { possestige } \\
\text { Desirability } \\
\text { Trendiness }\end{array} \\
\end{array}$ \\
\hline & Sensory fit & \begin{tabular}{|l|l} 
Fit in terms of feelings that a consumer & Fun to use \\
might have towards the brands & Appeal \\
& Trust in the brand \\
Admiration for the brand
\end{tabular} \\
\hline & Futuristic fit & \begin{tabular}{|l|l}
$\begin{array}{l}\text { Fit in terms of technological aspects of the } \\
\text { brand }\end{array}$ & Uniquenation \\
& Product variety \\
Design
\end{tabular} \\
\hline & Utilitarian fit & $\begin{array}{l}\begin{array}{l}\text { Fit in terms of quality aspects of the } \\
\text { brands }\end{array} \\
\text { Quality of material used } \\
\text { Quality of manufacturing } \\
\text { Long lastingness } \\
\text { Reliability }\end{array}$ \\
\hline
\end{tabular}

Source: Adapted from Hsieh and Lindridge (2005).

\section{Results}

Given the exploratory and predictive nature of the study (as opposed to theory building) the data were subjected to partial least squares (Chin and Newsted, 1999; Haenlin and Kaplan, 2004; Tenenhaus et al., 2005) using SmartPLS 3 (Ringle et al., 2014) with 500 samples. The composite reliability of all measures was above 0.8 and the corresponding AVE values were above 0.7 (Table 3 ). These indices are above the suggested benchmarks of 0.70 for the former and 0.50 for the latter (Fornell and Larcker, 1981) and thus confirm the psychometric properties of the latent constructs.

Table 3. Composite reliability and corresponding AVE values

\begin{tabular}{|c|c|c|c|c|}
\hline & \multicolumn{2}{|c|}{ Original Model } & \multicolumn{2}{|c|}{ Adapted Model } \\
\hline & CR & AVE & & \\
\hline Attitudes $_{A}$ & .944 & .893 & .944 & .893 \\
\hline Attitudes $_{B}$ & .950 & .905 & .948 & .894 \\
\hline Product fit & .886 & .795 & .886 & .795 \\
\hline Brand fit & .869 & .768 & & \\
\hline Economic fit & & & .898 & .689 \\
\hline Sensory fit & & & .869 & .624 \\
\hline Futuristic fit & & & .888 & .664 \\
\hline Utilitarian fit & & & .928 & .762 \\
\hline Symbolic fit & & & .913 & .724 \\
\hline Attitudes $_{\mathrm{AB}}$ & .986 & .958 & .989 & .958 \\
\hline Familiarity $_{A}$ & .901 & .752 & .901 & .752 \\
\hline Familiarity $_{B}$ & 897 & .745 & .897 & .745 \\
\hline
\end{tabular}

Source: Authors' own research. 
The results are presented in Table 4. Before discussing each measure, it is worth noting the improved fit for the adapted model; variance explained $\left(\mathrm{R}^{2}\right)$ and predictive relevance $\left(\mathrm{Q}^{2}\right)$ are both improved. As expected, attitudes to the parent brands are a significant influence on perceptions of the co-brand product. Brand fit is a significant influence on the brand alliance but product fit is not. Economic, futuristic and utilitarian fit are significant, while sensory and symbolic fit elements Familiarity did not moderate parent brand attitudes in the original model, but did interact significantly with brand fit for mobile phones in the adapted model.

Table 4. Comparison of models

\begin{tabular}{|c|c|c|}
\hline & $\begin{array}{l}\text { Original model } \\
\text { Path coefficient } f 2 \text { ( } p \text { values) }\end{array}$ & $\begin{array}{l}\text { Adapted model } \\
\text { Path coefficient } f 2(p \\
\text { values) }\end{array}$ \\
\hline $\begin{array}{l}\text { Attitudes to parent brand } \\
\left(\mathrm{Att}_{A}\right)\end{array}$ & $.153(.008)^{* *}$ & $.124(.032)^{*}$ \\
\hline $\begin{array}{l}\text { Attitudes to parent brand } \\
\left(\mathrm{Att}_{\mathrm{B}}\right)\end{array}$ & $-.119(.037)^{*}$ & $-.145(.015)^{*}$ \\
\hline Product category fit & $.080(.115)$ & $-.071(.144)$ \\
\hline $\begin{array}{l}\text { Brand fit } \\
\text { Brand Image fit }\end{array}$ & $.132(.023)^{*}$ & \\
\hline Economic fit & & $.284(.000)^{* * *}$ \\
\hline Sensory fit & & $-.042(.265)$ \\
\hline Futuristic fit & & $.168(.006)^{* * *}$ \\
\hline Utilitarian fit & & $.175(.004)^{* * *}$ \\
\hline Symbolic fit & & $-.016(.404)$ \\
\hline $\mathbf{A t t}_{A} *$ Familiarity $_{A}$ & $-.030(.329)$ & $.051(.226)$ \\
\hline Att $_{\mathrm{B}} *$ Familiarity $_{\mathrm{B}}$ & $-.082(.111)$ & $.109(.051)$ \\
\hline Brand fit $*$ Familiarity & $.089(.091)$ & $-.170(.005)^{* *}$ \\
\hline Brand fit $*$ Familiarity $_{B}$ & $-.039(.282)$ & $.041(.272)$ \\
\hline $\mathbf{R}^{2}, \operatorname{Adj} \mathbf{R}^{2}$ & $.128 ; .094$ & $.246 ; .202$ \\
\hline $\mathbf{Q}^{2}$ & .151 & .249 \\
\hline
\end{tabular}

Source: Authors' own research.

\section{Discussion}

The study reveals a number of interesting findings. First, the results show a negative relationship between the attitudes to the watch brands and perceptions of the co-brand product. This is unexpected, but on reflection it may reflect a confounding effect from the brands selected. Rolex had higher pre-alliance attitudes than Swatch. As a premium brand, any co-branding activity may be viewed suspiciously, even when specific elements of fit are considered. Conversely, Swatch may be less positively viewed (and may or may not fit with its partner mobile phone brand on various attributes) but any partnership activity that brings additional functionality might be viewed positively (Washburn et al., 2004). Brand economic, futuristic and utilitarian fit were significant influences on brand alliance perceptions, but sensory and symbolic fit were not. Economic fit suggests that when consumers perceive two brands to offer similar levels of price, value and affordability, the co-brand offering will be viewed more favourably. Futuristic fit encompasses the technological aspects of brand image, indicating that (all other things being equal) where levels of design, innovation and uniqueness are comparable between brands, the brand alliance will be more positively perceived. Utilitarian fit considers how well the brands are matched in terms of quality of manufacturing and materials, durability and reliability. Given that both watches and 
MMCKS mobile phones have a large and robust set of functional attributes, such as precision, robustness, visual appeal, ease-of-use, size, and added features, it may not be surprising that symbolic and sensory image fit were less important in the co-brand assessment. The lack of significant findings for these dimensions in conjunction with the negative relationship already noted between watch brands perceptions and the co-brands suggests that further refinements to these dimensions may be needed. Scrutiny of the interaction of brand fit and familiarity with the mobile phone reveals that where a respondent perceived high brand fit, but had low familiarity with the phone brand, the co-brand was well received. Where respondents had high familiarity with the mobile phone (and high perceived brand fit across the dimensions), the co-brand was not well received. We can only speculate on the source of this, but it may reflect perceived dilution of a favoured brand, and should be examined in future studies. Overall, the study suggests that an expanded measure of brand fit that considers brand image dimensions has more explanatory power.

\section{Limitations and directions for future research}

Only a few brands and product categories were used in this study; therefore any generalizations must be made with caution. Special attention must be paid when replicating the research for different brand pairings to clarify the relationships that are not mentioned in the study. In addition, it is reasonable to assume that the relative influence of brand image dimensions will vary with product category, depending on the importance of hedonic and utilitarian attributes, and additional categories should be considered. The study called for respondents to react to a hypothetical pairing of two real brands with high average familiarity. With novel pairings, consumer's lack of familiarity with the attributes inherent in the product category implies that dimensions of brand image fit play a varying role.

\section{Conclusions}

This study represents the first steps towards an enhanced (but parsimonious) measure of brand image fit in a brand alliance. The results suggest that when consumers evaluate a potential brand alliance, they consider independent dimensions of the brand image when assessing the fit between the brands, and that these perceptions influence their view of the co-branded product offering. This aligns with real world successful brand alliances (e.g. BMW/Louis Vuitton, Leica/Moncler, Google/Luxottica, Alexander Wang/H\&M, Snapchat/Square) which would not necessarily be deemed a strong fit if overall complementarity and consistency were the only considerations. The relative impact of the image dimensions is likely to vary with the importance of specific attributes to the product category (e.g. perfume vs. computers vs. restaurants). Future studies should consider other product pairings in order to identify these interrelationships and provide normative guidelines for potential brand partners.

Acknowledgements

We wish to thank Alex Kramer for her development of the advertising graphics.

\section{References}

Anderson, N.H. (1981), "Foundations of Information Integration Theory", The American Journal of Psychology, Vol. 95, No. 4, pp. 708-711.

Aaker, D.A., and Keller, K.L. (1990), "Consumer evaluations of brand extensions”, Journal of Marketing, Vol. 54, No. 1, pp. 27-41. 
Aaker, D.A. (1996),"Measuring brand equity across products and markets”, California Management Review, Vol. 38, No. 3, pp. 102-120.

Austin, J.R., Siguaw, J.A., Matilla, A.S. (2003), "A re-examination of the generalizability of the Aaker brand personality measurement framework", Journal of Strategic Marketing, Vol. 11, No. 2, pp. 77-92.

Azoulay, A., Kapferer, J.N. (2003), "Do brand personality scales really measure brand personality?" Journal of Brand Management, Vol. 11, No. 2, pp. 143-155.

Batra, R., Lehmann, D.R. and Singh, D. (1993), "The brand personality components of brand goodwill: some antecedents and consequences", in Aaker, D.A. and Biel, A. (Eds), Brand Equity \& Advertising: Advertising's Role in Building Strong Brands, Laurence Erlbaum Associates, Mahwah, NJ, Vol. 23, No. 8, pp. 639-666.

Baumgarth, C. (2004), "Evaluations of co-brands and spill-over effects: Further empirical results”, Journal of Marketing Communications, Vol. 10, No. 2, pp. 115131.

Belk, R. (1988),“Possessions and the extended self”, Journal of Consumer Research, Vol. 15, No. 3, pp. 139-168.

Berthon, P., Pitt, L.F., Campbell, C. (2009), "Does brand meaning exist in similarity or singularity?" Journal of Business Research, Vol. 62, No. 3, pp. 356-361.

Besharat, A. (2010), "How co-branding versus brand extensions drive consumers' evaluations of new products: A brand equity approach", Industrial Marketing Management, Vol. 39, No. 8, pp. 1240-1249.

Bhat, S., and Reddy, S.K. (2001), "The impact of parent brand attributes associations and effect on brand extension evaluation", Journal of Business Research, Vol. 53, No. 3, pp. 111-122.

Biel, K.A. (1992), "How brand image drives brand equity", Journal of Advertising research, Vol. 32, No. 1, pp. 6-12.

Bluemelhuber, C., Carter, L.L. and Lambe, C.J. "Extending the view of brand alliance effects: an integrative examination of the role of country of origin", International Marketing Review, Vol. 24, No. 2, pp. 427-433.

Bouten, L.M., Snelders, D., and Hultink, E.J. (2011), "The impact of fit measures on the consumer evaluation of new co-branded products", Journal of Product Innovation Management, Vol. 28, No. 4, pp. 455-469.

Buil, I., de Chernatony, L. and Martinez, E. (2008), "A cross-national validation of the consumer -based brand equity scale", Journal of Project and Brand Management, Vol. 17, No. 6, pp. 384-392.

Chin, W.W., and Newsted, P.R. (1999), "Structural equation modelling analysis with small samples using partial least squares", In Rick Hoyle (Ed.), Statistical Strategies for Small Sample Research, Sage Publications, Vol. 2, No. 1, pp. 9-42.

Desai, K.K., and Keller, K.L. (2002), "The effects of ingredient branding strategies on host brand extendibility", Journal of Marketing, Vol. 66, No. 1, pp. 73-93.

Diamantopoulos, A., Smith, G., and Grime, I. (2005), "The impact of brand extensions on brand personality: experimental evidence", European Journal of Marketing, Vol. 39, No. $1 / 2$, pp. 129-149.

Dickinson, S. and Barker, A. (2007), "Evaluations of branding alliances between nonprofit and commercial brand partners: the transfer of affect", International Journal of Non-profit and Voluntary Sector Marketing, Vol. 12, No. 1, pp. 75-89.

Dobnei, D. and Zinkham, G.M. (1990), "In search of brand image, a foundation analysis", Advances in Consumer Research, Vol. 17, No. 1, pp. 110-119. 
MMCKS Faems, D., Looy, B., and Debackere, K. (2005), "Exploration patterns in gazelle firms: A multiple case study in the internet technology industry", Journal of Product Innovation Management, Vol. 22, No. 1, pp. 238-250.

Farquhar, P.H. and Herr, P.M. (1991), "The dual structure of brand associations" in Aaker, D.A. and Biel, A.L. (Eds), Brand Equity and Advertising: Advertising's Role in Building Strong Brands, Laurence Erlbaum Associates, Hillsdale, NJ, pp. 263277.

Folkes, V.S. (1988), "Recent Attribution research in consumer behaviour: a review and new directions", Journal of Consumer Research, Vol. 14, No. 4, pp. 548-565.

Fornell, C. and LArcker, D.F. (1981), "Structural equation models with unobservable variables and measurement error: algebra and statistics", Journal of Marketing Research, Vol. 18, No. 2, pp. 39-50

Friedmann, R. (2006), "Psychological meaning of products: Identification and marketing applications", Psychology and Marketing, Vol. 3, No. 1, pp. 1-15.

Gensch, D.H. (1978), "Image-measurement segmentation", Journal of Marketing Research, Vol. 15, No. 3, pp. 384-394.

Haenlein, M., and Kaplan, A.M. (2004), "A beginner's guide to partial least squares analysis", Understanding Statistics, Vol. 3, No. 4, pp. 283-297.

Helmig, B., Huber, J., and Leeflang, P. (2007), "Explaining behavioural intentions toward co-branded products. Journal of Marketing Management, Vol. 23, No. (3-4), pp. 285-304.

Hillyer, C., and Tikoo, S. (1995), Effect of cobranding on consumer product evaluations", Advances in Consumer Research, Vol. 22, No. 1, pp. 123-127.

Hsieh, M.H., and Lindridge, A. (2005), "Universal appeals with local specifications", Journal of Product and Brand Management, Vol. 14, No. 1, pp. 14-28.

James, D.O., Lyman, M., and Foreman, S.K. (2006), "Does the tail wag the dog? Brand personality in brand alliance evaluation", Journal of Product and Brand Management, Vol. 15, No. 3, pp. 173-183.

Keller, K.L. (1993), “Conceptualizing, measuring, and managing customer-based brand equity", Journal of Marketing, Vol. 57, No. 1, pp. 1-22.

Kim, H. and Roedder John, D. (2008), "Consumer response to brand extension: construal level as a moderator of the importance of perceived fit", Journal of Consumer Psychology, Vol. 18, No. 2, pp. 116-126.

Kirmani, A. and Zeithaml, V. (1991), "Advertising, perceived quality and brand image", in Aaker, D.A. and Biel, A.L. (Eds), "Brand Equity and Advertising: Advertising's Role in Building Strong Brands", Laurence Erlbaum Assocaites, Hillsdale, NJ, Vol. 9, No. 3, pp. 125-134.

Kocak, A., Abimbola, T. and Ozer, A. (2007), "Consumer brand equity in a cross-cultural replication: an evaluation of a scale", Journal of Marketing Management, Vol. 23, No. $1 / 2$, pp. 157-173.

Lanseng, E.J. and Olsen, L.E. ( 2012), "Brand alliances: the role of brand concept consistency", European Journal of Marketing, Vol. 46, No. 9, pp. 1108-1126.

Lafferty, B.A. (2007)," The relevance of fit in a cause-brand alliance when consumers evaluate corporate credibility", Journal of Business Research, Vol. 60, No. 5, pp. 447-453.

Lafferty, B.A., Goldsmith, R.E., and Hult, G.T.M. (2004), "The impact of the alliance on the partners: A look at cause-brand alliances", Psychology and Marketing, Vol. 21, No. 7, pp. 509-531. 
Lau, K.C., and Phau, I. (2007), "Extending symbolic brands using their personality: Examining antecedents and implications towards brand image fit and brand dilution", Psychology and Marketing, Vol. 24, No. 5, pp. 421-444.

Lee, J.K., Lee, B.K., and Lee, W.N. (2013), "Country-of-origin fit's effect on consumer product evaluation in cross-border strategic brand alliance", Journal of Business Research, Vol. 66, No. 3, pp. 354-363.

Levin, I.P., and Levin, A.M. (2000), "Modeling the role of brand alliances in the assimilation of product evaluations", Journal of Consumer Psychology, Vol. 9, No. 1, pp. 43-52.

Loken, B., and John, D.R. (1993), "Diluting Brand beliefs: when do brand extensions have a negative impact?" Journal of Marketing, Vol. 57, No. 3, pp. 71-84.

Low, G.S. and Lambe, C.W. Jr (2000), "The measurement and dimensionality of brand associations", Journal of Product and Brand Management, Vol. 9, No. 6, pp. 350368.

Lynch Jr, J.G., Chakravarti, D., and Mitra, A. (1991), "Contrast effects in consumer judgments: Changes in mental representations or in the anchoring of rating scales? Journal of Consumer Research, Vol. 18, No. 3, pp. 284-297.

Malhotra, N.K. (1988), "Self-concept and product choice: an integrated perspective", Journal of Economic Psychology, Vol. 19, No. 1, pp. 1-28.

Martinez, E., Cheratony, L. (2004), "The effect of brand extension strategies upon brand image", Journal of Consumer Marketing, Vol. 21, No. 1, pp. 39-50.

Martinez, E., Pina, J.M. (2003), "The negative impact of brand extensions on parent brand image", Journal of Product and Brand Management, Vol. 12, No. 7, pp. 432448.

McCarthy, M., Heath, T., and Milberg, S. (2001), "New brands versus brand extensions, attitudes versus choice: experimental evidence for theory and practice", Marketing Letters, Vol. 12, No. 1, pp. 75-90.

Meyers-Levy, J., Tybout, A.M. (1989), "Schema congruity as a basis for product evaluation", Journal of Consumer Research, Vol. 16, No. 1, pp. 39-54.

O'Donohoe, S. (1994), "Advertising uses and gratifications", European Journal of Marketing, Vol. 28, No. 8/9, pp. 52-75.

Pappu, R., Quester, P.G., and Cooksey, R.W. (2005), “Consumer -based brand equity: improving the measurement - empirical evidence", Journal of Product and Brand Management, Vol. 14, No. 3, pp. 143-154.

Park, C.W., Jaworski, B.J. and MacInnis, D.J. (1986), "Strategic Brand Concept-Image Management”, Journal of Advertising, Vol. 50, No. 4, pp. 135-145.

Park, C.W., Jun, S.Y., and Shocker, A.D. (1996), "Composite branding alliances: An investigation of extension and feedback effects", Journal of Marketing Research, Vol. 18, No. 2, pp. 453-466.

Park, C.W., Milberg, S., and Lawson, R. (1991), "Evaluation of brand extensions: The role of product feature similarity and brand concept consistency", Journal of Consumer Research, Vol. 17, No. 1, pp. 185-193.

Petty, R.E., and Cacioppo, J.T. (1986), "The elaboration likelihood model of persuasion", Advances in Experimental Social Psychology, Vol. 19, No. 1, pp. 123205.

Rao, A.R., Qu, L., and Ruekert, R.W. (1999), "Signalling unobservable product quality through a brand ally", Journal of Marketing Research, Vol. 36, No. 2, pp. 258-268.

Rao, A.R., and Ruekert, R.W. (1994), "Brand alliances as signals of product quality", Sloan Management Review, Vol. 36, No. 2, pp. 87-89. 
MMCKS Reynolds, T.J., and Gutman, J. (1984), "Advertising is image management", Journal of Advertising Research, Vol. 24, No. 1, pp. 27-37.

Ries, A. and Trout, J. "Marketing Warfare”, Journal of Consumer Marketing, Vol. 3, No. 4, pp. 77-82.

Ringle, C.M., Wende, S., and Becker, J.M. (2014), Smart PLS 3. Hamburg: SmarltPLS Retrieved from http://www.smartpls.com

Rodrigue, C.S., and Biswas, A. (2004), "Brand alliance dependency and exclusivity: An empirical investigation", Journal of Product and Brand Management, Vol. 13, No. 7, pp. 477-487.

Romaniuk, J., Bogomolova, S. and Dall'Olmo Riley, F. (2012), "Brand image and brand usage: is a forty-year-old empirical generalization still useful?", Journal of Advertising Research, Vol. 52, No. 2, pp. 243-251.

Salinas, E.M. and Perez, J.M.P. (2009), "Modeling the brand extensions' influence on brand image", Journal of Business Research, Vol. 62, No. 1, pp. 50-60.

Simonin, B.L., and Ruth, J.A. (1998), "Is a company known by the company it keeps? Assessing the spill over effects of brand alliances on consumer brand attitudes", Journal of Marketing Research, Vol. 35, No. 1, pp. 30-42.

Singh, J., Kalafatis, S.P., and Ledden, L. (2014), "Consumer perceptions of cobrands: The role of brand positioning strategies", Marketing Intelligence and Planning, Vol. 32, No.2, pp. 145-159.

Tenenhaus, M., Vinzi, V.E., Chatelin, Y., and Lauro, C. (2005), "PLS path modelling", Computational Statistics and Data Analysis, Vol. 48, No. 1, pp. 159205.

Van der Lans, R., Van den Bergh, B., and Dieleman, E. (2014), "Partner selection in brand alliances: An empirical investigation of the drivers of brand fit", Marketing Science, Vol. 33, No. 4, pp. 551-566.

Vasquez, R., Del Rio, B. and Iglesias, V. (2002), "Consumer-based brand equity: development and validation of a measurement instrument", Journal of Marketing Management, Vol. 18, No. 1/2, pp. 27-48.

Walchi, S.B. (2007), "The effects of between-partner congruity on consumer evaluation of co-branded products", Psychology \& Marketing, Vol. 24, No. 11, pp. 947-973.

Washburn, J.H. and Plank, R.E. (2002), "Measuring Brand Equity: An Evaluation of a consumer-based brand equity scale", Journal of Marketing Theory and Practice, Vol. 10, No. 1, pp. 46-62.

Washburn, J.H., Till, B.D., and Priluck, R. (2000), “Co-branding: Brand equity and trial effects”, Journal of Consumer Marketing, Vol. 17, No.7, pp. 591-604.

Washburn, J.H., Till, B.D., and Priluck, R. (2004), "Brand alliance and customer-based brand-equity effects", Psychology and Marketing, Vol. 21, No. 7, pp. 487-508.

Xiao, N. and Lee, S.H. (2014), "Brand identity fit in co-branding: the moderating role of C-B identification and consumer coping", European Journal of Marketing, Vol. 48, No. 7/8, pp. 1239-1254.

Zdravkovic, S., Magnusson, P. and Stanley, S.M. (2010), "Dimensions of fit between a brand and a social cause and their influence on attitudes", International Journal of Research in Marketing, Vol. 27, No. 1, pp. 151-160. 
Appendix: Advertisement example

MMCKS

283

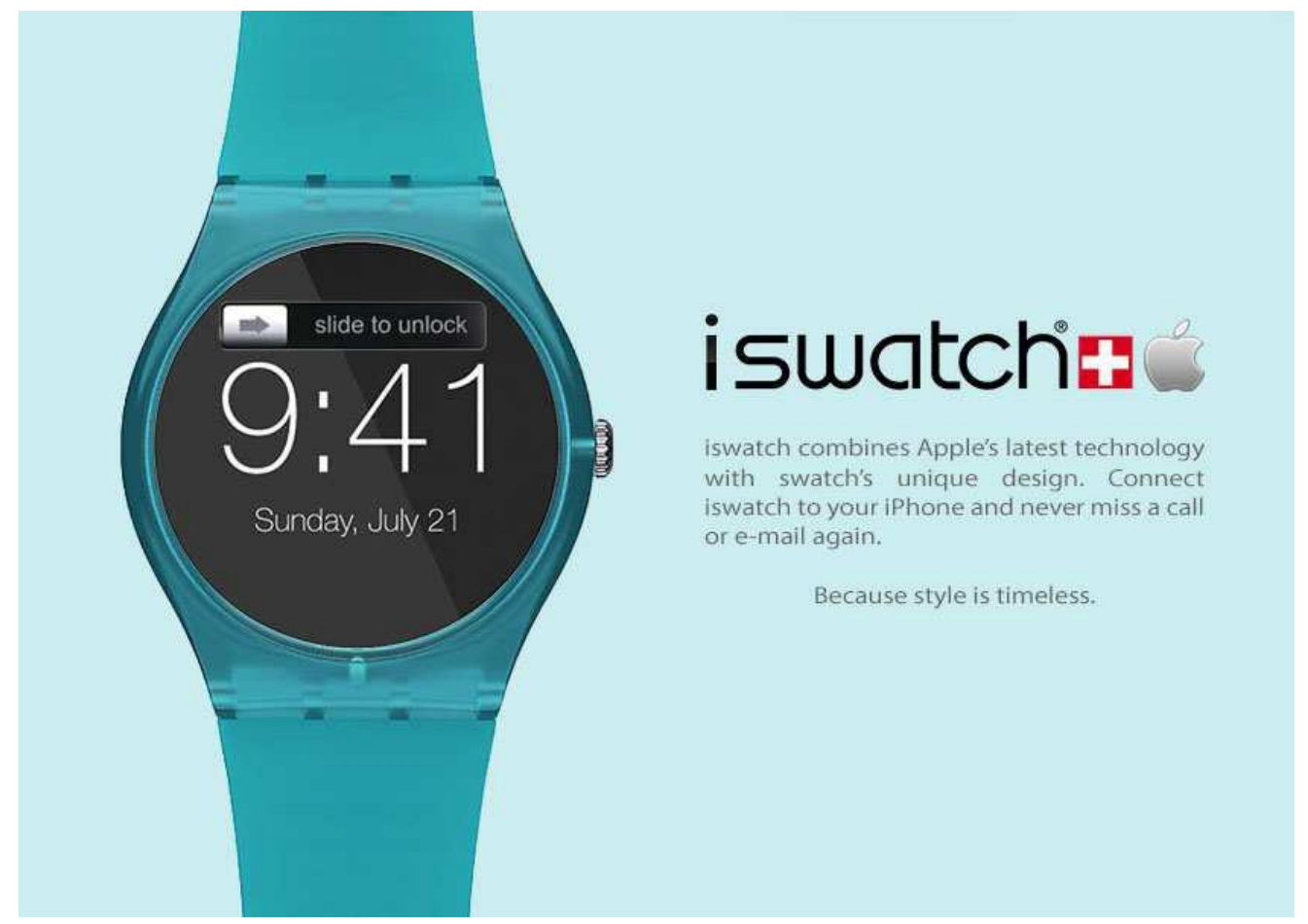

